\title{
Modeling hydrological ecosystem services and tradeoffs: a case study in Baiyangdian watershed, China
}

\author{
Yang Bai $\cdot$ Hua Zheng $\cdot$ Zhiyun Ouyang • \\ Changwei Zhuang $\cdot$ Bo Jiang
}

Received: 14 April 2011/Accepted: 27 November 2012/Published online: 13 December 2012

(C) Springer-Verlag Berlin Heidelberg 2012

\begin{abstract}
Policy makers and scientists consider that land use strategies are designed to provide direct benefits to people by protecting vital ecosystem services. However, due to lack of information and evaluation methods, there is no effective and systematic tool for assessing tradeoffs between direct human benefits and ecosystem services. Land use changes influence ecosystem properties, processes and components, which are the basis for providing services. Five alternative land use scenarios (no conversion of agricultural lands, no urban expansion, agricultural expansion, forestry expansion, and riparian reforestation) were modeled for the Baiyangdian watershed, China, a densely populated, highly modified watershed with serious water shortage and pollution problems. The model InVEST (Integrated Valuation of Ecosystem Services and Tradeoffs) is designed to inform decisions about natural resource management, with an aim to align economic forces with conservation. Three ecosystem services (agricultural production, hydropower production, and water quality) were modeled to balance direct benefits and hydrological ecosystem services using InVEST. The results showed that: hydropower production was the greatest in the forestry expansion, but the lowest in agricultural expansion;
\end{abstract}

Y. Bai $\cdot$ H. Zheng $(\bowtie) \cdot$ Z. Ouyang $\cdot$ B. Jiang

State Key Laboratory of Urban and Regional Ecology, Research Center for Eco-Environmental Sciences, Chinese Academy of Sciences, Beijing 100085, China e-mail: zhenghua@rcees.ac.cn

Y. Bai

Institute of Applied Ecology, Shanghai Academy of Environmental Sciences, Shanghai 200233, China

C. Zhuang

Nanjing Institute of Environmental Sciences, Ministry of Environmental Protection, Nanjing 210042, China agricultural production was reduced the most in forestry expansion, while retained the most in riparian reforestation. Riparian reforestation also provided the highest $\mathrm{N}$ and $\mathrm{P}$ retention and lowest $\mathrm{N}$ and $\mathrm{P}$ exportation. Riparian reforestation was the optimal land use strategy, since it protected and enhanced the vital ecosystem services without undermining direct human benefits. This research presents an initial analytical framework for integrating direct human benefits and ecosystem services in policy planning and illustrates its application. Although there are important potential tradeoffs between ecosystem services, this systematic planning framework offers a means for identifying valuable synergies between conservation and development.

Keywords Ecosystem services - Tradeoffs - Scenarios · InVEST

\section{Introduction}

Ecosystem services are the benefits that humans derive from ecosystems, which include provisioning, regulatory, supporting and cultural services (Millennium Ecosystem Assessment 2003; de Groot et al. 2002; Egoh et al. 2009). The evaluation of ecosystem services is one of the common issues in ecological economics (Costanza et al. 1997; Daily et al. 2000). Better decisions regarding the sustainable use and management of ecosystem services are made by analyzing and quantifying the importance of ecosystems to human well-being (Chen et al. 2009).

With the rapid increase in human population and the over consumption of natural resources, the demands for ecosystem services often surpass their provisioning capacity (Vitousek et al. 1997; Bennett et al. 2005). Humans frequently enhance the production of some services at the 
expense of the others (Jackson et al. 2001; Zhang et al. 2010). Development has generated significant economic and social benefits, but these benefits have often come at high costs associated with the deterioration of natural capital and ecosystem services through processes such as soil erosion, reduced quantity and quality of fresh water, salinity, and biodiversity depletion (Tilman 1999). Ready access to market exchange results in managers of privately owned natural capital stocks preferentially producing marketed ecosystem services at the expense of non-market services. Over time, this results in the under-supply of the latter and the long-term deterioration of the natural capital stocks and ecosystem service flows (Lant et al. 2008; Yang et al. 2010). The Millennium Ecosystem Assessment (MA 2005) focused on services of different ecosystems, stressing their overall decline (Dolinar et al. 2010). Continuing ecosystem services loss urgently requires techniques to rapidly assess and monitor changes in ecosystem services (Balvanera et al. 2001; Menon and Bawa 1997; Margules and Pressey 2000; Ramesh et al. 1997; Stork and Samways 1995; Krishnaswamy et al. 2009).

When decision makers and scientists set out to explore the possible redesign of landscapes, often at different scales, they need information about their ecological function and how a change in the mix of land use will impact on tradeoffs between production needs and other human needs. If possible, tradeoffs should be quantified in terms of the sustainable delivery of ecosystem goods and services from resilient ecosystems and be matched to human well-being (Bennett et al. 2009; Yapp et al. 2010). To make better decisions, a systematic account of the relationships between ecosystem management and the generated ecosystem services is needed (de Groot et al. 2010). There are recent assessments of natural capital and ecosystem services (e.g., Blashke 2005; Haines-Young et al. 2006; Chan et al. 2006; Naidoo and Ricketts 2006; Gimona and Van der Horst 2007; Egoh et al. 2008; Meyer and Grabaum 2008; Grêt-Regamey et al. 2008; Naidoo et al. 2008; Raymond et al. 2009). However, they are not suitable for representing services at a single location or assessing the spatial and temporal services change. Dynamic visualization alternatives under different developing scenarios need to be explored to represent changing services in space and time (de Groot et al. 2010). Due to lack of original data and effective evaluation methods, there has been little research about tradeoffs between direct benefits and other vital ecosystem services. There are no effective and systematic methodologies for land use management that link ecosystem services.

This study focuses on the application of InVEST (Integrated Valuation of Ecosystem Services and Tradeoffs) (Tallis et al. 2008), a model developed to measure and evaluate ecosystem services under land management scenarios reflecting different priorities, illustrated through a case study of the Baiyangdian watershed, China. The
Baiyangdian watershed is a human-dominated watershed with serious water shortage and pollution problems, in which agricultural land accounts for nearly $37 \%$ of the total area. The broad aim of this study is to provide guidance to organizations for better designing and promoting sustainable land management in Baiyangdian watershed. The methodology presented here demonstrates the impacts of contrasting hypothetical land use scenarios with different policy objectives on the delivery of ecosystem services, and the synergies and tradeoffs between them. Given this challenge, two questions are addressed:

(1) How to map and assess ecosystem services across landscape scale?

(2) How to manage tradeoffs of several ecosystem services in a watershed?

\section{Study area and methods}

\section{Study area}

The Baiyangdian watershed (Fig. 1) is located in the middle of the North China Plain and covers an area of $31,200 \mathrm{~km}^{2}$. It has a complex topography with higher lands in the west and lower lands in the east. Mountainous areas are mainly covered with forest and grass, which account for $64 \%$ of the total area; plain areas are mainly cropland. Forest, grass, and cropland account for 26.13, 26.74 and $36.57 \%$ of the total area, respectively. According to the weather records from the past 50 years (from Baoding, Shijiazhuang, Wutaishan, Weixian, and Huailai weather stations within or adjacent to the watershed), the mean annual temperature is between 6.8 and $12.7^{\circ} \mathrm{C}$ (the daily maximum value is $43.3{ }^{\circ} \mathrm{C}$ and the daily minimum value is $-30.6{ }^{\circ} \mathrm{C}$ ), the mean annual precipitation is $548 \mathrm{~mm}$ and the mean annual pan evaporation is $1,500-2,000 \mathrm{~mm}$. The Baiyangdian watershed has a high population density, more than 448 people $\mathrm{km}^{-2}$; compared to 45 people $\mathrm{km}^{-2}$ of the average population density worldwide. The area also suffers from extreme water shortage. The water availability per capita is $297 \mathrm{~m}^{3}$ (the annual average water availability is 3.12 billion $\mathrm{m}^{3}$ ). Due to natural conditions and human activities in recent years, river flow has decreased and is polluted with urban domestic sewage, industrial waste and agricultural pesticides and fertilizers, causing serious contamination. The environment of Baiyangdian watershed is undergoing serious threats.

Land use scenarios

Five alternative land use and land cover (LULC) scenarios were developed to examine the potential synergies of 
Fig. 1 The Baiyangdian watershed

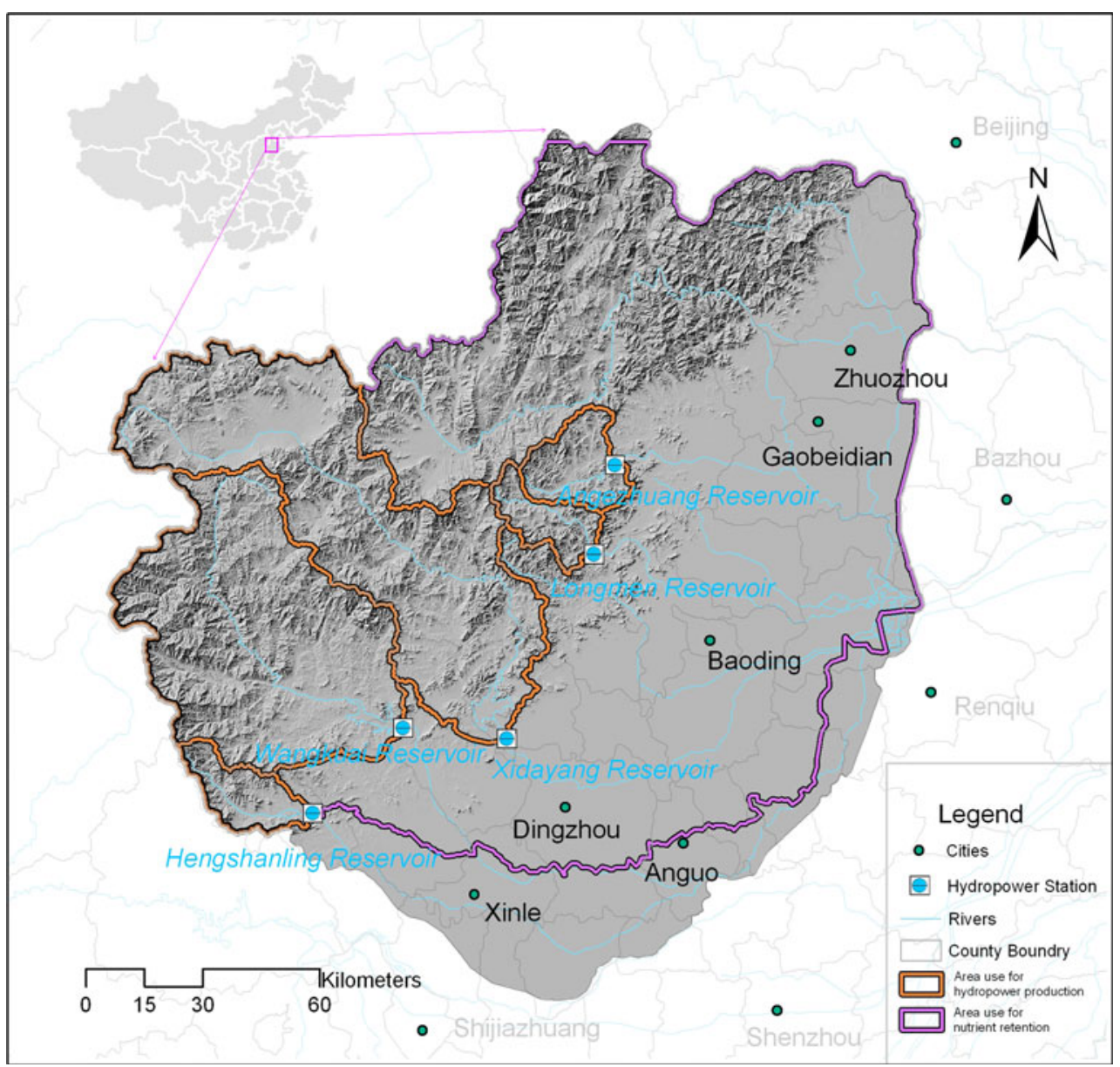

tradeoff in the delivery of ecosystem services among land uses. These were chosen to reflect the current situation and alternative uses under different policy options. Alternative scenarios were developed as follows.

\section{Se1: No agricultural lands converted scenario}

No conversion of agricultural lands between 1980 and 2007. Due to rapid urbanization and population growth, the urban area increased and agricultural lands decreased dramatically in this area.

\section{Se2: No urban expansion scenario}

All land use conversions to urban areas were reverted to their 1980 land use.

\section{Se3: Agricultural expansion scenario}

Based on a land suitability assessment of the Baiyangdian watershed, the most productive lands that were not in agriculture as of 2007 were converted to agriculture by 2007 , with the exception of urban areas and open water.

\section{Se4: Forestry expansion scenario}

Based on a land suitability assessment of the Baiyangdian watershed, all land most suitable for forestry that was not forested as of 2007 was converted to forestry. Urban areas, open water and the most highly productive agricultural lands were the only exceptions to this rule. These areas retained their actual LULC.

\section{Se5: Riparian reforestation}

In this scenario, a 50-m buffer zone was established on both sides along the river network considering local reality and the conversion costs. Due to lack of water resources infrastructure, farm land is often distributed along rivers for easy irrigation in the Baiyangdian watershed. The wider the buffer zone is selected, the more farm land will be converted to forest, which will increase the conversion costs. All lands in the buffer zone were placed into forestry. 

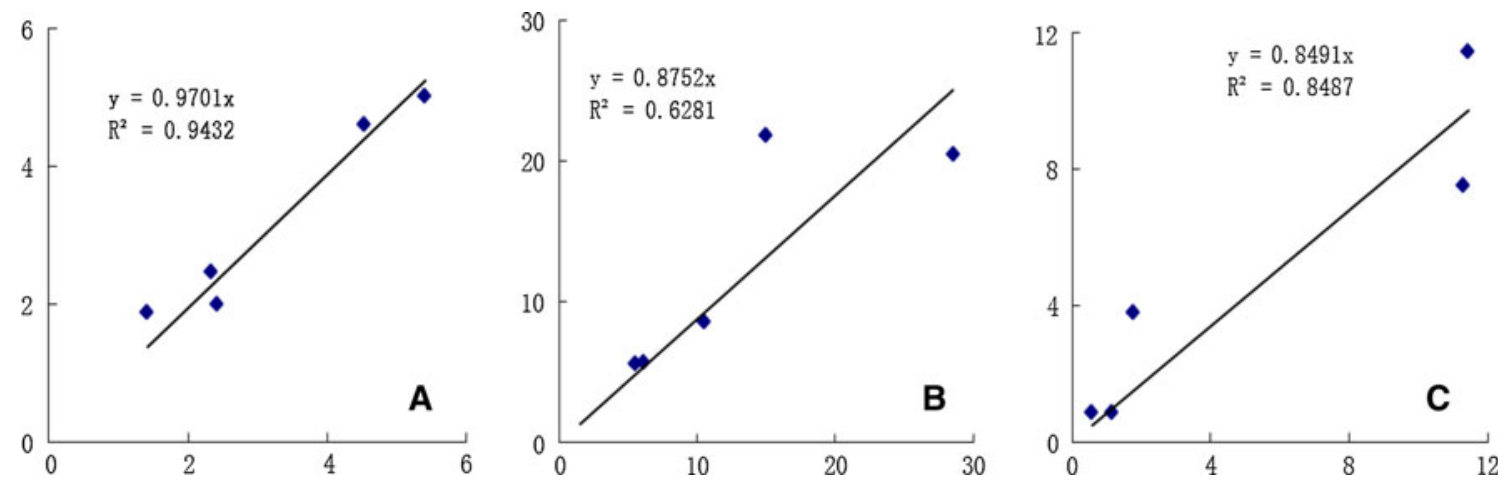

Fig. 2 The observed data versus predicted data (Note that $x$-axis is observed value, while $y$-axis is predicted value. a water yield, $10^{8} \mathrm{~m}^{3}$ per year; b $\mathrm{N}$ exportation, ton per year; $\mathbf{c} \mathrm{P}$ exportation, ton per year.)

Table 1 The results of $t$ test

\begin{tabular}{llll}
\hline & SD & $t$ & Sig. \\
\hline Water yield & 0.376 & 0.197 & 0.853 \\
N retention & 5.31 & 0.307 & 0.774 \\
P retention & 0.596 & 0.293 & 0.784 \\
\hline
\end{tabular}

Urban areas and open water in 1980 were the only exceptions to this rule. These areas retained their actual LULC.

\section{InVEST description}

InVEST uses land use and land management information along with environmental conditions as inputs into ecological production functions to generate spatially explicit predictions of ecosystem service supply. By varying land use or land management input and evaluating the output from InVEST, information can be provided to managers about the likely impacts of their choices on the joint provision and value of ecosystem services. This information can be used to compare alternative management options in terms of biophysical measures of services, the overall value of services generated, or disaggregated information about various stakeholders that may benefit or be harmed (Daily et al. 2009; Nelson et al. 2009). For this application, hydropower, water quality (nitrogen and phosphorus), and agricultural production in each scenario were modeled. The assumptions and limitations of each module will be discussed in the following part.

\section{Hydropower production}

The InVEST Reservoir Hydropower model estimates the relative contributions of water from different parts of a landscape, offering insight into how changes in land use patterns affect annual surface water yield and hydropower production. This model has several limitations. First, the model assumes that all water produced in a watershed in excess of evapotranspiration arrives at the watershed outlet, without considering water capture by means other than primary human consumptive uses. Second, the model assumes that hydropower production and pricing remain constant over time. Third, this model is based on annual averages, which neglect extremes and do not consider the temporal dimensions of water supply and hydropower production. Fourth, the model does not consider sub-annual patterns of water delivery timing. Fifth, the model describes consumptive demand by LULC type. Finally, a single variable is used to represent multiple aspects of water resource allocation, which may misrepresent the complex distribution of water among used and over time (Tallis et al. 2008).

Table 2 Alternative LULC under different scenarios (ha)

\begin{tabular}{|c|c|c|c|c|c|c|}
\hline & 2007 & $\mathrm{Se} 1$ & $\mathrm{Se} 2$ & $\mathrm{Se} 3$ & $\mathrm{Se} 4$ & $\mathrm{Se} 5$ \\
\hline Agriculture & $1,011,720$ & $1,103,470$ & $1,176,190$ & $1,480,830$ & 910,610 & 992,125 \\
\hline Grassland & 739,678 & 745,882 & 746,748 & 411,897 & 397,948 & 613,775 \\
\hline Open water & 28,302 & 73,380 & 32,373 & 50,160 & 27,896 & 23,637 \\
\hline Urban area & 258,783 & 118,999 & 81,729 & 205,103 & 256,754 & 249,493 \\
\hline Wasteland & 4,983 & 4,218 & 5,051 & 1,417 & 3,312 & 4,772 \\
\hline Forestland & 723,102 & 720,617 & 724,481 & 617,159 & $1,170,050$ & 882,768 \\
\hline
\end{tabular}


Table 3 Tradeoff of hydrological services under different scenarios

\begin{tabular}{|c|c|c|c|c|c|}
\hline & \multirow[t]{2}{*}{ Water yield (million $\mathrm{m}^{3}$ ) } & \multicolumn{2}{|l|}{ Retention } & \multicolumn{2}{|l|}{ Exportation } \\
\hline & & $\mathrm{N}$ (million kg) & $\mathrm{P}$ (million $\mathrm{kg}$ ) & $\mathrm{N}$ (million kg) & $\mathrm{P}$ (million $\mathrm{kg}$ ) \\
\hline 2007 & 360.91 & 28.60 & 0.96 & 9.18 & 0.45 \\
\hline $\mathrm{Se} 1$ & 385.98 & 24.93 & 1.05 & 6.15 & 0.40 \\
\hline $\mathrm{Se} 2$ & 372.50 & 24.75 & 1.11 & 5.58 & 0.43 \\
\hline $\mathrm{Se} 3$ & 138.31 & 30.62 & 1.25 & 9.86 & 0.65 \\
\hline $\mathrm{Se} 4$ & 584.08 & 27.84 & 0.92 & 8.91 & 0.42 \\
\hline $\mathrm{Se} 5$ & 432.34 & 30.66 & 1.27 & 5.26 & 0.24 \\
\hline
\end{tabular}

Fig. 3 Mapping hydropower productions in scenarios


\section{Highest value area \\ Lowest value area}

\section{Water quality}

The InVEST water quality model evaluates the pollutant retention service provided by a landscape and highlights the impacts of land use change on water quality when provided with alternative LULC scenarios. Although there are multiple potentially significant impairments of water quality, in this study we focused on nitrogen $(\mathrm{N})$ and phosphorus $(\mathrm{P})$. 

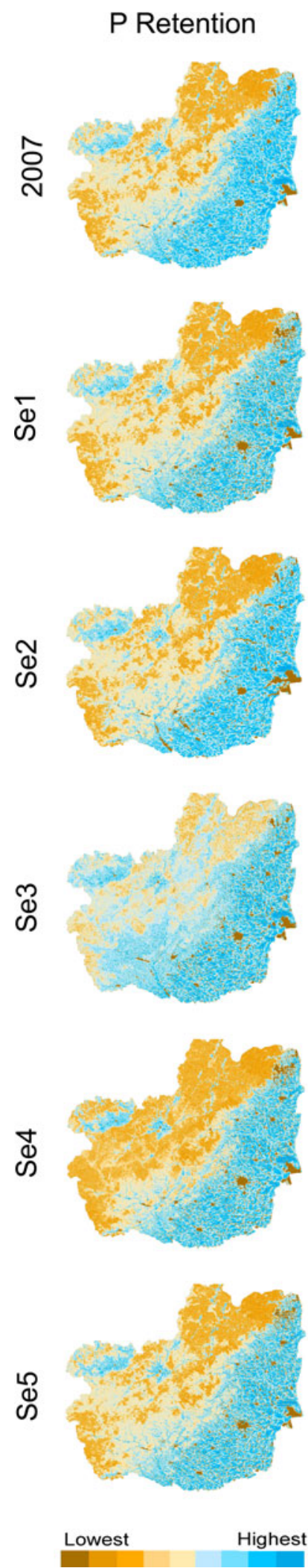

\section{N Retention}
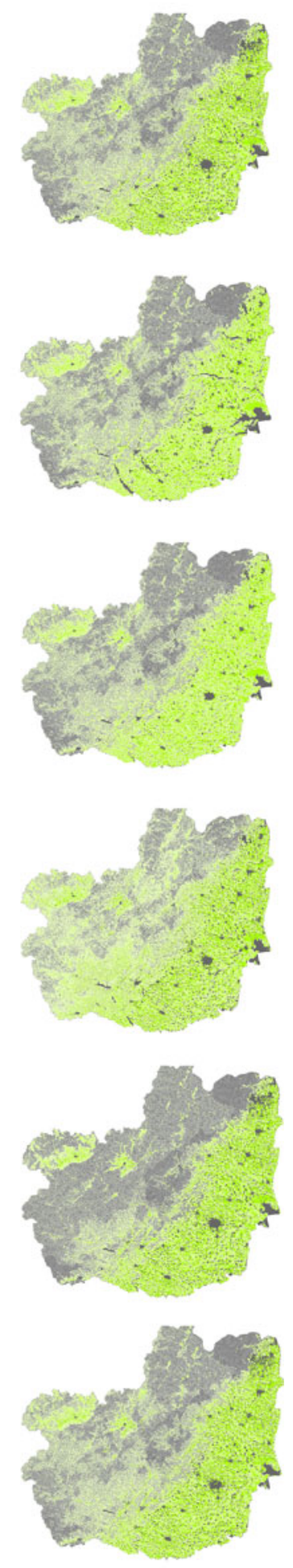

Lowest

Highest

Fig. 4 Mapping $\mathrm{N}$ and $\mathrm{P}$ retention in scenarios

This model has several assumptions. First, this model may be less applicable to locations where the hydrology is

determined by rainfall intensity; in areas where flashy rains are predominant and where infiltration excess runoff occurs. Second, the model can only assess one pollutant per run. Third, in some cases, the model may provide an inaccurate marginal cost for pollutant removal (Tallis et al. 2008).

\section{Agricultural production}

InVEST uses information on the observed relationships between soil quality and yields, observed yield trends, observed prices for agricultural produce, and agricultural production costs to estimate the annual net market returns of agricultural production. Combining expected yield with crop prices generates an estimate of revenue. Subtracting costs from revenues generates an estimate of economic returns from agricultural activity.

\section{Model validation for water quality}

Five actual measurement points were selected in this watershed. Each point has monitoring data of yearly water yield and water quality. Those on-site measured data were used to validate InVEST model. The graphs show the correlations between the observed and predicted data (Fig. 2). The $t$ test accepts the null hypothesis at the default $\alpha=0.05$ significance level (Table 1). Under the null hypothesis, there is no extreme difference between observed and predicted data, as indicated by the $p$ value $(0.853,0.774$ and 0.784 , respectively), which is higher than $\alpha$.

\section{Results}

Land use change

Table 2 shows the actual (2007) and the five alternative LULC scenarios. The area of agriculture was the greatest in Se3 (1,480,830 ha), and smallest in Se4. Se5 was the scenario most closely resembling the actual area of agriculture in 2007. Se 3 had the smallest area of forested land, with 105,943 ha less forested area compared with 2007. Forested lands were greater than actual condition for both $\mathrm{Se} 4$ and $\mathrm{Se} 5$, but the difference for $\mathrm{Se} 4$ was 2.8 times that of Se5. Due to the expansion of agricultural and forest land, grasslands decreased dramatically both in $\mathrm{Se} 3$ and $\mathrm{Se} 4$. The urban area decreased dramatically in both $\mathrm{Se} 1$ and $\mathrm{Se} 2$.

\section{Ecosystem service changes}

Based on the water yield model, the amount of water used for hydropower was 360.91 million $\mathrm{m}^{3}$ in 2007 , and its value was 21.91 million dollars. Compared with 2007, hydropower production decreased in Se3 (by 13.51 million 
Fig. 5 Changes to hydrological services under different scenarios compared to 2007

Fig. 6 Hydrological services change association with $1 \%$ agricultural change (based on 2007 scenario)
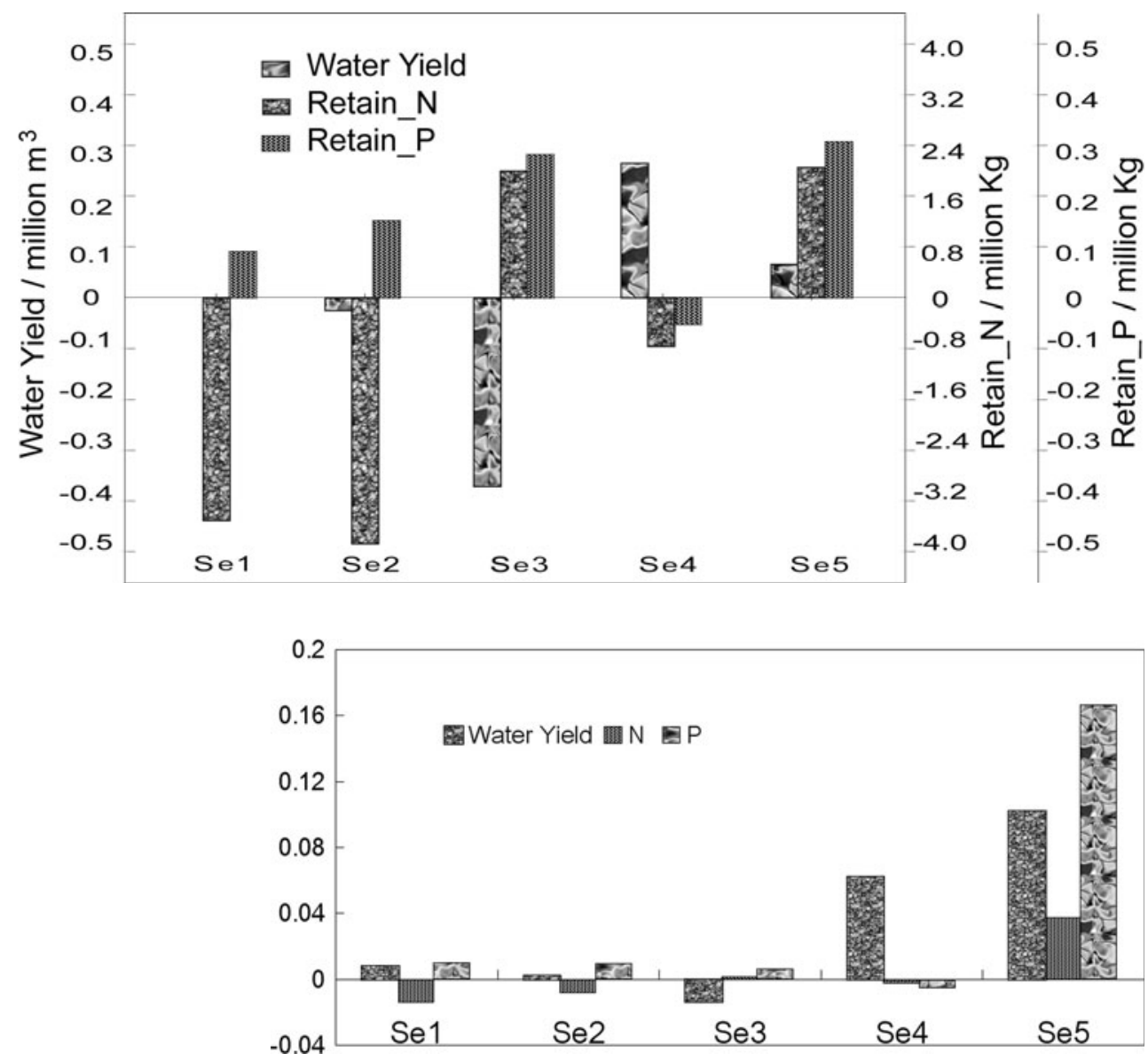

dollars). Hydropower production increased with forestland expansion, with Se4 increasing by 13.55 million dollars and Se5 increasing by 4.34 million dollars (see Table 3; Fig. 3). As for water yield, $\mathrm{Se} 4$ and $\mathrm{Se} 5$ are better than $\mathrm{Se} 1$, $\mathrm{Se} 2$ and Se3. The water yield in Se4 and Se5 are 584.08, 432.34 million $\mathrm{m}^{3}$, and 385.98, 372.50, 138.31 million $\mathrm{m}^{3}$ in $\mathrm{Se} 1, \mathrm{Se} 2, \mathrm{Se}$, respectively.

The total $\mathrm{N}$ retention in 2007 was 28.60 million $\mathrm{kg}$. Se5 had the highest $\mathrm{N}$ retention, with 30.66 million $\mathrm{kg}$. Se3 was the second highest, with 30.62 million $\mathrm{kg}$. Se 2 had the least $\mathrm{N}$ retention, with 24.74 million $\mathrm{kg}$. Compared with 2007, N retention decreased in $\mathrm{Se} 1, \mathrm{Se} 4$, and especially in $\mathrm{Se} 2$, while $\mathrm{Se} 5$ increased more than $\mathrm{Se} 3$. From the perspective of land use type, the highest $\mathrm{N}$ retention was caused by agriculture under all scenarios, followed by grassland and forestland. Compared to 2007, the amount of $\mathrm{N}$ retention in agriculture only increased for $\mathrm{Se} 3$, while it decreased dramatically in Se1. Conversely, the amount of $\mathrm{N}$ retention for forested lands increased for $\mathrm{Se} 3, \mathrm{Se} 4$ and Se5, with highest increasing for Se5 (see Table 3; Figs. 4, 5). This means Se5 can provide the highest $N$ retention services throughout the whole scenarios.

The total $\mathrm{P}$ retention in 2007 was 0.96 million $\mathrm{kg}$. Se5 had the highest $\mathrm{P}$ retention, with 1.27 million $\mathrm{kg}$. Se3 was the second highest, with 1.25 million $\mathrm{kg}$, and $\mathrm{Se} 4$ the least, with 0.92 million $\mathrm{kg}$. Compared with 2007, P retention only decreased in $\mathrm{Se} 4$; Se5 increased the most, by 0.31 million $\mathrm{kg}$. Comparing land use types, the greatest $\mathrm{P}$ retention was caused by agriculture under all scenarios, followed by grassland and forestland. Compared to 2007, the amount of $\mathrm{P}$ retention increased for all scenarios except $\mathrm{Se} 4$; on the other hand, the amount of $\mathrm{P}$ retention in forest land increased for all scenarios, especially in Se5 (see Table 3; Figs. 5, 6). This means Se5 can provide the highest $\mathrm{P}$ retention services throughout the whole scenarios.

\section{Discussion}

The present study focuses on the management of ecosystems to protect the current human direct benefits without sacrificing hydrological ecosystem services. The direct income for local people is mainly from agriculture. In other words, the greater the area of agricultural land, the greater the direct benefit they will gain, to some extent. However, expansion of agriculture without planning can cause serious environmental problems. This research assessed the 


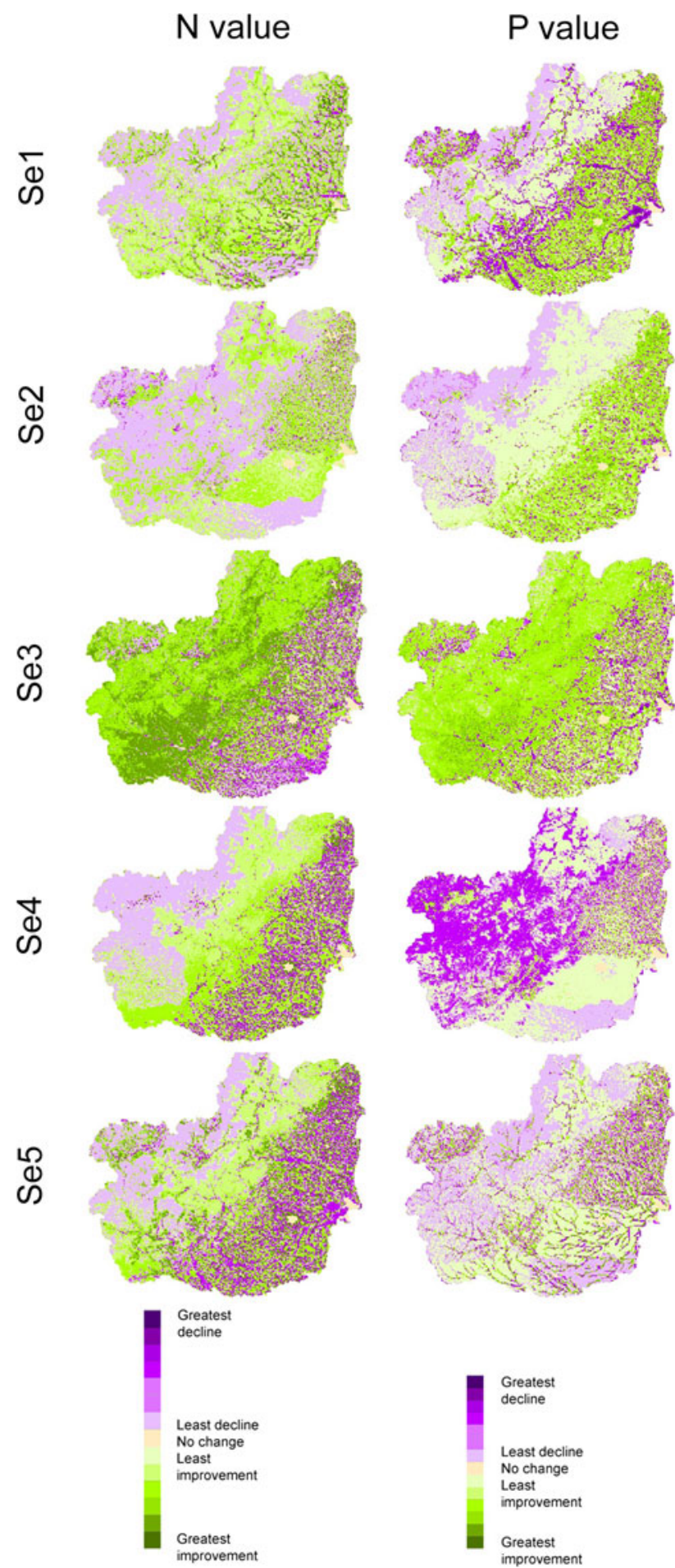

Fig. 7 Mapping $\mathrm{N}$ and $\mathrm{P}$ retention changes in scenarios (based on 2007)

tradeoffs between direct benefits and hydrological ecosystem services and selected the best scenario.

Table 3 and Fig. 6 show the tradeoff among different ecosystem services for the five land use scenarios. Agricultural production for both $\mathrm{Se} 1$ and $\mathrm{Se} 2$ was similar to the actual condition (2007). However, $\mathrm{N}$ and $\mathrm{P}$ retention was too low, resulting in high $\mathrm{N}$ and $\mathrm{P}$ exportation, which degraded the water quality downstream. Agricultural production was the highest for $\mathrm{Se} 3$ but its $\mathrm{N}$ and $\mathrm{P}$ exportation was the greatest too $(\mathrm{N}$ : 9.65 million $\mathrm{kg}$ and $\mathrm{P}$ : 0.65 million $\mathrm{kg}$ ). Se4 yielded the highest hydropower production, but its agricultural production was only 1.41 billion units, and its $\mathrm{N}$ and $\mathrm{P}$ exportation was very high. In $\mathrm{Se} 4$, hydropower production increased but this was at the cost of agricultural production, which declined dramatically. This kind of land use strategy is not sustainable in the long run, since the unilateral pursuit of environmental protection and reforestation occurs largely at the expense of the local people's direct benefits. Se5 was also a forestland expansion strategy, but the result was very different. The increase in forested area for Se5 was far lower than that of $\mathrm{Se} 4$ (compared to 2007), but the $\mathrm{N}$ and $\mathrm{P}$ retention was greatest and the $\mathrm{N}$ and $\mathrm{P}$ exportation was lowest (Fig. 4). The direct human benefits decreased only slightly, and its hydropower production ranked second among all scenarios. This means that $\mathrm{Se} 5$ was the optimal land use management strategy, since it guarantees agricultural production while also increasing hydrological ecosystem services. Se5 also indicated the importance of riparian vegetation protection.

\section{Conclusions}

Most researchers only consider the single value of ecosystem services, without evaluating how the services are generated during different land use management strategies and without assessing how small land use changes would influence the services (Costanza et al. 1997). Such information might improve awareness of the value of natural ecosystems; however, it cannot provide a good basis for policy formulation and guidance. Water management in agriculture is a key component in solving some of the most pressing tradeoffs between an increase in agricultural production that can contribute to food security and economic growth on the one hand, and dealing with the losses of important ecosystem benefits that also sustain human well-being and livelihoods on the other (Gordon et al. 2010). In response to this complex challenge, using the InVEST model, three kinds of ecosystem services were analyzed under different land use scenarios.

Se5 was the optimal sustainable land use strategy, since it could gain the best social and environmental benefits. These results suggest that ecological regulation can insure local people direct benefits as well as improve other ecosystem services. Tradeoffs in this research cannot only help making reasonable ecosystem management strategies, but also assist natural resource managers in prioritizing areas where remnant vegetation should be retained or 
rehabilitated (Fig. 7). With this information, adjacent landholders can improve their management and remnant vegetation through gaining the ecosystem service benefits, and further are able to profit from grant applications and incentives. The next step may be to find the most ecologically sensitive areas or priority areas for conservation. The methodology from this research can also be used to address these challenges.

Acknowledgments We gratefully acknowledge the financial support of the National Basic Research Program of China (Grant No. 2009CB421105), the International Cooperation Program of the Chinese Academy of Science (Grant No. GJHZ0948) and Special Fund in the Public Interest of Ministry of Land Resources of the People's Republic of China (201011018).

\section{References}

Balvanera P, Daily GC, Ehrlich PR, Ricketts TH, Bailey SA, Kark S, Kremen C, Pereira H (2001) Conserving biodiversity and ecosystem services. Science 291:2047

Bennett EM, Peterson GD, Levitt EA (2005) Looking to the future ecosystem services. Ecosystems 8:125-132

Bennett EM, Peterson GD, Gordon LJ (2009) Understanding relationships among multiple ecosystem services. Ecol Lett 12:1394-1404

Blashke T (2005) The role of the spatial dimension within the framework of sustainable landscapes and natural capital. Landsc Urban Plan 75(3-4):198-226

Chan KMA, Shaw MR, Cameron DR, Underwood EC, Daily GC (2006) Conservation planning for ecosystem services. PLoS Biol 4:e379

Chen NW, Li HC, Wang LH (2009) A GIS-based approach for mapping direct use value of ecosystem services at a county scale: management implications. Ecol Econ 68:2768-2776

Costanza R, d'Arge R, de Groot R, Farber S, Grasso M, Hannon B, Limburg K, Naeem S, O’Neill RV, Paruelo J, Raskin RG, Sutton P, van den Belt M (1997) The value of the world's ecosystem services and natural capital. Nature 387(6630): $253-260$

Daily GC, Soderqvist T, Aniyar S, Arrow K, Dasgupta P, Ehrlich PR, Folke C, Jansson A, Jansson BO, Kautsky N, Levin S, Lubchenco J, Maler KG, Simpson D, Starrett D, Tilman D, Walker B (2000) Ecology-the value of nature and the nature of value. Science 289(5478):395-396

Daily G, Polasky S, Goldstein J, Kareiva PM, Mooney HA, Pejchar L, Ricketts TH, Salzman J, Shallenberger R (2009) Ecosystem services in decision-making: time to deliver. Front Ecol Environ $7(1): 21-28$

de Groot R, Wilson MA, Boumans MR (2002) A typology for the classification, description and valuation of ecosystem functions, goods and services. Ecol Econ 41:393-408

de Groot RS, Alkemade R, Braat L, Hein L, Willemen L (2010) Challenges in integrating the concept of ecosystem services and values in landscape planning, management and decision making. Ecol Complex 7(3):260-272

Dolinar N, Rudolf M, Sraj N, Gaberscik A (2010) Environmental changes affect ecosystem services of the intermittent Lake Cerknica. Ecol Complex 7(3):403-409

Egoh B, Reyers B, Rouget M, Richardson DM, Le Maitre DC, van Jaarsveld AS (2008) Mapping ecosystem services for planning and management. Agric Ecosyst Environ 127:135-140
Egoh B, Reyers B, Rouget M, Bode M, Richardson DM (2009) Spatial congruence between biodiversity and ecosystem services in South Africa. Biol Conserv 142:553-562

Gimona A, Van der Horst D (2007) Mapping hotspots of multiple landscape functions: a case study on farmland afforestation in Scotland. Landsc Ecol 22:1255-1264

Gordon CLJ, Max F, Malin F (2010) Managing water in agriculture for food production and other ecosystem services. Agric Water Manag 97:512-519

Grêt-Regamey A, Bebi P, Bishop ID, Schmid W (2008) Linking GISbased models to value ecosystem services in an Alpine region. J Environ Manag 89(3):197-208

Haines-Young R, Watkins C, Wale C, Murdock A (2006) Modelling natural capital: the case of landscape restoration on the South Downs, England. Landsc Urban Plan 75:244-264

Jackson RB, Carpenter SR, Dahm CN, McKnight DM, Naiman RJ, Postel SL, Running SW (2001) Water in a changing world. Ecol Appl 11:1027-1045

Krishnaswamy J, Bawa KS, Ganeshaiah KN, Kiran MC (2009) Quantifying and mapping biodiversity and ecosystem services: utility of a multi-season NDVI based Mahalanobis distance surrogate. Remote Sens Environ 113:857-867

Lant CL, Ruhl JB, Kraft SE (2008) The tragedy of ecosystem services. Bioscience 58(10):969-974

Margules CR, Pressey RL (2000) Systematic conservation planning. Nature 405:243-253

Menon S, Bawa KS (1997) Applications of Geographic Information Systems (GIS), remote-sensing, and a landscape ecology approach to biodiversity conservation in the Western Ghats. Curr Sci 73:134-145

Meyer BC, Grabaum R (2008) MULBO-model framework for multi criteria landscape assessment and optimisation. A support system for spatial land use decisions. Landsc Res 33:155-179

Millennium Ecosystem Assessment (2003) Ecosystems and human well-being: a framework for assessment. World Resources Institute, Washington, DC

Millennium Ecosystem Assessment (2005) Ecosystems and human well-being. World Resource Institute Island Press, Washington, $\mathrm{DC}$

Naidoo R, Ricketts TH (2006) Mapping the economic costs and benefits of conservation. PLoS Biol 4:e360

Naidoo R, Balmford A, Costanza R, Fisher B, Green RE, Lehner B, Malcolm TR, Ricketts TH (2008) Global mapping of ecosystem services and conservation priorities. Proc Natl Acad Sci USA 105(28):9495-9500

Nelson E, Mendoza G, Regetz J, Polasky S, Tallis H, Cameron DR, Chan KMA, Daily G, Goldstein J, Kareiva P, Lonsdorf E, Naidoo R, Ricketts TH, Shaw MR (2009) Modeling multiple ecosystem services, biodiversity conservation, commodity production, and tradeoffs at landscape scales. Front Ecol Environ 7(1):4-11

Ramesh BR, Menon S (1997) Map of Biligiri Rangaswamy Temple Wildlife Sanctuary, vegetation types and land use. French Institute, Pondicherry

Raymond CM, Bryan BA, MacDonald DH, Cast A, Strathearn S, Grandgirard A, Kalivas T (2009) Mapping community values for natural capital and ecosystem services. Ecol Econ 68:1301-1315

Stork NE, Samways MJ (1995) Inventorying and monitoring. In: Heyward VH (ed) Global biodiversity assessment. Cambridge Press, New York, pp 453-543

Tallis HT, Ricketts T, Ennaanay D, Nelson E, Vigerstol K, Mendoza G, Wolny S, Olwero N, Aukema J, Foster J, Forrest J, Cameron D (2008) InVEST 1.003 beta User's Guide. The Natural Capital Project, Stanford

Tilman D (1999) Global environmental impacts of agricultural expansion: the need for sustainable and efficient practices. Proc Natl Acad Sci USA 96:5995-6000 
Vitousek PM, Monney HA, Lubchenco J, Melilo J (1997) Human domination of earth's ecosystems. Science 277:494-499

Yang WH, Brett AB, Darla HM, John RW, Geoff W, Neville DC, Jeffrey DC (2010) A conservation industry for sustaining natural capital and ecosystem services in agricultural landscapes. Ecol Econ 69:680-689
Yapp G, Walker J, Thackway R (2010) Linking vegetation type and condition to ecosystem goods and services. Ecol Complex 7(3):292-301

Zhang B, Li W, Xie GD (2010) Ecosystem services research in China: progress and perspective. Ecol Econ 69(7):1389-1395 